Vol 12, Issue 3, 2019

\author{
Print - 0974-2441 \\ $\underline{\text { Review Article }}$
}

\title{
CONSUMMATED REVIEW ON PROSTATITIS
}

\author{
HARINE AG, SUMITRA M*, CHITRA V \\ Department of Pharmacology, SRM College of Pharmacy, SRM Institute of Science and Technology, Kattankulathur, Chennai, Tamil Nadu, \\ India. Email: sumi26379@gmail.com
}

Received: 24 August 2018, Revised and Accepted: 28 November 2018

\begin{abstract}
Prostatitis is an inflammatory disease, when the prostate is vulnerable to infectious stimuli like urinary pathogens, are changes in the lifestyle leads to inflammation in the prostate gland. It is a pathological state where the swelling of prostate occur to most of the men and mainly elderly. Recently, prostatitis is a dangerous threat for men almost 50\% total men population. The review comprises complete information regarding prostatitis and its related complications. The compilation of the data is about the disease from classification of prostatitis, causative agents, symptoms, treatment, mitigation, natural and alternative therapy to improve the quality of life. Awareness of this disease is not known to the majority of the population when it is left untreated identification and treatment at the right time help in increase in recovering from the pathological condition of the victim to overcome.
\end{abstract}

Keyword: Urinary pathogens, Prostatitis, Causative agents, Alternative therapy.

(C) 2019 The Authors. Published by Innovare Academic Sciences Pvt Ltd. This is an open access article under the CC BY license (http://creativecommons. org/licenses/by/4. 0/) DOI: http://dx.doi.org/10.22159/ajpcr.2019.v12i3.29307

\section{INTRODUCTION}

The prostate gland is an essential male reproductive organ which is a muscular gland present beneath the bladder the and surrounds urethra about the size of a small apricot its pivot function is to secrete prostate fluid and also help propel seminal fluid into the urethra during ejaculation. The action of the prostate gland is similar to the epiglottis, that is, the urethra is the only path for excreting the urine from the bladder, and also the semen fluids are discharged. Vas deferens passed through the prostate gland and connected to the urethra, during the ejaculation millions of sperm moves from testes through vas deferens into the region of the prostate gland. At this point, prostate gland regulates the movement of sperm into the urethra by contraction causing a closing off, opening bladder, and urethra [1].

The prostate fluid makes up the about one-third of the total volume of semen, enzymes zinc, and citric acid, the liquid is slightly acid in nature and the fluid secreted by the seminal vesicle is alkaline. This alkalinity helps to protect sperm, prolong their life in an acidic environment of the vagina.

Prostate-specific antigen (PSA) is an enzyme which is one of the major components of the prostatic fluid that regulate the sperm motility, liquefying semen during ejaculation and thickened after ejaculation. PSA aids the biochemical change.

Prostatitis is state of inflammation of prostate gland which causes which cause painful and difficult in urination and obstruct the vas deferens which connect urethra. Almost half of the men in their 60 years suffer from the growth of the prostate called benign prostatic hyperplasia (BPH), according to the Ohio State University Medical Centre. By the age of 70-80, they are prone to nearly $90 \%$ chance of developing BPH. Symptoms include urination, dribbling, and a stuttered or weak stream.

\section{EPIDEMIOLOGY}

The prevalence of prostatitis can occur from young adult men to elders; there are various reasons for the occurrence of prostate inflammation is mainly due to urinary tract infection especially bacteria is one of the significant factors affecting. Acute bacterial prostatitis (ABP) is acquired by $50 \%$ of men commonly. CP/CPPS incidence lies between
2 and 16\% worldwide in men below 50 years old [2]. Symptoms can found on average 87 months prior diagnosis. Its undesirable impact on quality of life (QOL) compares to other illnesses. The relative prevalence of other entities among men with prostatitis is 10 to $65 \%$ nonbacterial prostatitis and 30 to $80 \%$ prostatodynia.

\section{CATEGORIES OF PROSTATITIS}

The National Institute of Health (NIH) consensus has categorized prostatitis into four distinct types are (a) acute prostatitis, (b) chronic bacterial, (c) inflammatory/non-inflammatory chronic, and (d) asymptomatic inflammatory [1].

\section{ABP}

Acute prostatitis is caused by bacteria that infect the prostate gland and cause inflammation and pain it lasts for a short time, i.e. for 3 weeks to $<3$ months which are called acute prostatitis. When it extends its spam beyond the stipulation of 3 months, called as chronic bacterial prostatitis. The causative agents for inflammation and infection of the prostate are Escherichia coli in mostly and also Chlamydia trachomatis, Enterococcus spp., Klebsiella pneumonia, Neisseria gonorrhea, Proteus mirabilis, Pseudomonas aeruginosa, and Staphylococcus aureus $[3,4]$. These bacteria invade the prostate gland and cause infection by consuming contaminated animal products (example chicken), discharge of urination in an unsanitary environment, and contract through sexual activity from a partner who has a bacterial infection. Men suffering from chronic who intermittently perform self-catheterization, indwelling catheters, immunosuppression, and diabetes mellitus, are at higher risk of acquiring $\mathrm{ABP}$ due to their increased risk of bacterial colonization of the urethra.

The clinical exhibition of ABP may be highly variable with symptoms ranging from mild to severe. Symptoms include:

- Fever

- Dysuria

- Perineal or lower abdominal pain

- Urinary urgency

- Urinary frequency

- Hematospermia

- Painful ejaculation. 
$\mathrm{ABP}$ has to be deliberate in the diagnosis of the male with urinary tract infection symptom. During the physical examination, tender palpation of the prostate gland generally acknowledges a pathognomonic finding of an impeccably tender, boggy prostate gland, care should be taken to avoid vigorous prostate massage as this may precipitate bacteremia and sepsis.

ABP diagnosed clinically, in spite of both urine culture and urine Gram stain and are recommended to find causative organisms and determine treatment. While C-reactive protein and blood cultures are essential, a PSA test not indicated. PSA elevations are common in the setting of infection and may take up to 1-month post-infection to resolve. Imaging only shows imaging is performed when a prostatic abscess suspect in a patient with $\mathrm{ABP}$ who is failing to improve with treatment, in order to differentiate between and acute bacterial prostatitis and prostate cancer.

\section{CHRONIC BACTERIAL PROSTATITIS}

Chronic prostatitis also caused by the above bacteria and also the by Trichomonas vaginalis, Ureaplasma urealyticum, Mycoplasma hominids, and Serratia marcescens these do not grow in the standard condition, and it is hard to identify and treat these bacteria are quite rare in affecting nearly $80 \%$ cases are E. coli and C. trachomatis, Enterococcus spp., K. pneumonia, N. gonorrhoea, and P. mirabilis. A study has shown that $8 \%$ of chronic prostatitis had positive specific polymerase chain reaction assay. Chronic prostatitis patient has a distinct variety of bacterial DNA encoding sequence despite extensive negative microbiological investigations [5].

Chronic pelvic pain syndrome or chronic prostatitis (CPPS/CP) and interstitial cystitis/bladder pain syndrome defined by the absence of identifiable bacterial infection as a cause for the chronic pain and urinary symptoms. It classified into two types they are inflammation subtype and non-inflammation subtype according to the NIH. The etiology of this type is poorly understood both inflammatory and infectious mechanism have postulate [6-8]. Psychological stress may be a major contributor to symptom severity [9]. Some data prevail of a correlation between fibromyalgia, chronic fatigue syndrome, and irritable bowel syndrome with CP/CPPS, although certain association exists between the number of inflammatory markers detected within the prostate gland and the degree of symptoms $[10,11]$.

Symptoms of CP/CPPS are a weak urinary stream, dysuria, urinary frequency, urinary urgency, pain in the lower abdomen, perineum, testicles or penis; hematospermia or difficulty achieving an erection $[12,13]$. According to diagnosis in the patient to have pelvic pain or urinary symptoms for more than three of the previous 6 months with no evidence of ABP or urinary tract infection in that time [14]. CPPS/CP accounts for $90 \%$ of prostatitis cases in outpatient clinics and characterized by chronic pelvic pain symptoms lasting at least 3 months during the past 6 months, in the absence of a urinary tract bacterial infection but the presence of urinary symptoms and sexual dysfunction.

\section{ASYMPTOMATIC INFLAMMATORY PROSTATITIS}

Asymptomatic inflammatory prostatitis refers on to the word asymptomatic. During infertility or prostate cancer evaluation, this asymptomatic inflammatory prostatitis diagnosed incidentally. [15] According to the clinical indication of category IV prostatitis i.e., asymptomatic inflammatory prostatitis is unaware by the patients and is often left untreated; because there is an inflammation of the prostate but there is no symptoms of genital urinary tract infection has no symptoms of pelvic pain. There are two typical signs of asymptomatic inflammatory prostatitis, the presence of white blood cells or pus cells in the urine and elevated PSA level; this condition commonly observed in BPH.

\section{CONSEQUENCES OF PROSTATITIS}

Chronic inflammation of prostatitis plays a significant role in pathogenesis and progression of $\mathrm{BPH}$ and prostate cancer according to preclinical trials [16].

\section{BPH}

Approximately $40-70 \%$ of patients suffering in BPH-related lower urinary tract symptoms (LUTS) found with chronic inflammation pathologic evaluation [16]. Recent studies exploring inflammasomes in prostate showed prostate expression of nucleotide-binding domain leucine-rich repeat protein 1 (NLRP1), NLRP3, and absent-in-melanoma 2 [17-19], though BPH and prostatitis are distinct entities, there are significant clinical overlap and critical inflammatory component in both [19]. Inflammation has also viewed as a relevant factor in the pathogenesis of BPH. Studies showed infiltrating lymphocytes in the development and progression of prostate adenoma as an effect of a self-maintaining remodeling process [21]. Histological analysis of prostatic tissue remains the only available method to diagnose chronic inflammation. However, chronic inflammation of prostate may be associated with prostatic calcifications, prostate volume, LUTS severity, storage, and prostatitis-like symptoms, inadequate response to medical therapies and urinary biomarker [22]. Chronic inflammation could be a predictor of insufficient response to BPH medical treatment. Studies had shown that men with BPH related LUTS and chronic prostate inflammation might have increased risk of symptom progression and acute urinary retention during follow-up.

\section{PROSTATE CANCER}

Inflammation had been found in about $20 \%$ of all human malignancies in a tissue microenvironment. Chronic inflammation is an inducer for most prostate malignancy. Chronic inflammation which aids to prostate cancer tissue when medically treated by surgery has given an adverse outcome. Prostate epithelium may damage with various environmental factor they are infectious agents, dietary carcinogens, and hormonal changes which trigger procarcinogenic inflammatory process and leads to cell transformation. Proliferative inflammatory atrophy, mainly in the peripheral prostate zone, refers to chronic inflammation and carcinogenesis cooccurring. This a probable precursor of prostatic intraepithelial neoplasia and prostate cancer [23]. Transcription factor nuclear factor-kappa B (NF-kB) activation has been recognized as the significant effecter of pro-inflammatory processes as well as of prostate cancer pathogenesis [24]. Inflammatory cytokines will promote NF-B complexes for anti-apoptotic signaling in prostate cancer cells. Although signals provided by NF-kB activators are necessary not sufficient for NLRP3 activation [25], NF-kB activation can be promoted through positive feedback with inflammatory cytokines. However, some studies suggest inflammation may relate with lower. Prostate cancer risk $[26,27]$ and some showed that inflammatory genes expressed differently among races in prostate cancer [28,29].

\section{CAUSE OF PROSTATITIS}

Various modes of stimuli and components occur the cause of prostatitis. And also, due to unhealthy habitat and diet are majorly proposed to the vulnerable causative agents of the various categories of prostate inflammation or prostatitis [30].

\section{INFECTIOUS STIMULI}

Uropathogens mainly Gram-negative bacilli are most often causes bacterial prostatitis, and Gram-positive identified as the causative organism of chronic prostatitis $C$. trachomatis and trichomonasvaginalis are common pathogens cause chronic prostate inflammation sexually transmitted diseases. In general, these categories of prostatitis caused due to unhygienic urination, and unhealthy sexual habits play a key role in infectious prostatitis.

\section{NON INFECTIOUS STIMULI}

Prostatic inflammation is of multiple etiologies. Urine refluxed freely into the prostatic ducts [31] can provide a route for bacterial colonization [32,33]. Other potential factors include dietary components, changes in serum testosterone and estrogen levels autoimmunity, and reflux of harmful chemicals in the urine. Besides, 
prostate inflammation can trigger metabolic alterations including metabolic syndrome and dyslipidemia [34-36]. Recent studies showed that smoking and a high-fat diet might relate with prostate inflammation. In a univariable analysis in Reduction by Dutasteride of Prostate Cancer Events study, smoking associated with chronic prostate inflammation. Current smokers were prone to have acute inflammation and chronic inflammation in the baseline biopsy [37]. On the other hand, a highfat diet may induce oxidative stress and inflammation in the prostate gland by driving the nicotinamide adenine dinucleotide phosphate oxidase system and generating reactive oxygen species (ROS) [38]. A high-fat diet also causes a significant increase in proinflammatory cytokines through activation of Signal Transducer and Activator of Transcription-3 and NF-kB pathway. Both these pathways involved in proliferation, survival, angiogenesis, invasion, and inflammation in the prostate.

\section{SEROUS COMPONENT OF PROSTATE}

Besides, the cytokines directly made by cellular counterparts of prostate inflammation, the resistance has special sorts of activation in prostate inflammation. There are two sorts of patterns of the stimuli which will activate the innate system; one is pathogen-associated molecular patterns (PAMPs), and also an alternative is dangerassociated molecular patterns (DAMPs), that is, especially molecules derived from broken or dying cells. These patterns are recognized by pattern recognition receptors (PRRs), which can found in specialized epithelia, immune cells, and alternative tissues. PRRs divided into five families, together with toll-like receptors (TLRs), C-type lectins, retinoic acid-inducible gene-I-like receptors, and HIN-200, and NLRs. The means some members of the NLR and HIN-200 families answer DAMPs or PAMPs are by forming supramolecular structures called inflammasomes. They will typically mix adapter molecules similar to apoptosis-associated speck-like supermolecule (ASC). These structures activate the aminoalkanoic acid enzyme caspase-1, that cleaves pro-interleukin 1 beta (IL-1b) to IL-1b and pro-IL-18 to IL-18. These mature cytokines are pro-inflammatory, and so they trigger a typical inflammatory response. The inflammasome is called once the PRR that organizes it. Parenthetically, NLRP3 is associate in nursing inflammasome organized by NACHT, LRR, and PYD domains-containing supermolecule three, that play a crucial role in many urologic pathology. Typically the chronic inflammation starts with inflammasome, which is initiated by a canonical and noncanonical pathway [39-42].

The first step, priming is related to ligand binding to a non NLR receptor. It can increase the expression of inflammasome components. For instance is LPS binding to Toll-like receptor 4 (TLR4), that increase the expression of ASC, NLRP3, Caspase-1, and pro-IL-Ib [43].

Priming additionally promotes preexistent NLRP3 by deubiquitination, thus refer it for activation. IL-18 usually constitutively expressed.

The second step, activation is triggered by certain stimuli and result in cellular changes. Stimuli events embrace the presence of ROS, extracellular adenosine triphosphate binding with the purinergic receptor, or insoluble crystals damaging the semipermeable membrane. Cellular changes embrace production of ROS, potassium efflux from the cell, translocation of NLRP3 to the mitochondria; this leads to the mitochondrial degradation with unleashing of DNA and cardiolipin, and activation, which triggers nucleation of ASC proteins. They will interact with procaspase-1, and promote autoproteolytic maturation of caspase- 1 . Activated caspsase- 1 is then free from the complex and cleaves pro-IL-Ib and pro-IL-I8 to their mature forms. Active caspase-1 may also cleave gasdermin $\mathrm{D}$ which can begin a lytic necrobiosis process called proptosis [44-46]. Inflammation exacerbation increased in proptosis, as a result of it ends in the discharge of the mature Il-1b, IL-18, and DAMPs such as uric acid [47], ATP, and high motile group box 1. High motile group box 1 (HMGB1), which then activate inflammasome in neighbour cells. The free ASC-containing increases the uptake by macrophages, which start inflammasome activation within, or mature procytokinines in extracellular in extracellular space. $\mathrm{N}$ terminus osgasdermin D itself can also promote NLRP3 dependent activation of caspase-1 [48].

The non-canonical pathway is the alternative way of activating NLRP3 inflammasome complex. There involve caspase- 4 and 5 in humans and caspase-11 in rodents [49-51]. These caspases are activated by directbinding to intracellular bacteria or LPS. Once activated, caspase-11 can trigger the formation of the macromolecular inflammasome and activates downstream events. However, caspase-11 can also cleave gasdermin directly and induce pyroptosis even without inflammasome formation

Seminal plasma IL-8 (SIL-8) appears to be the most reliable and predictive marker of prostatitis [52]. Furthermore, the evidence is emerging on SIL-8 involvement in inflammation not only of the prostate but also of other male genital tract organs, in particular, seminal vesicles and epididymis, but not testis. SIL-8 is strongly related to leukocytospermia, and a tight inverse correlation with ejaculate volume has demonstrated, which may correlate with ejaculatory duct and seminal vesicle abnormalities.

\section{CELLULAR COMPONENT OF PROSTATE INFLAMMATION}

In the initial stage of $\mathrm{ABP}$, the infection of micro-organism promotes neutrophils and macrophages continued by lymphocytic infiltration in the advanced stages [53]. Later the acute phase, the majority of infiltrative leukocytes in the inflamed prostate are chronically activate $\mathrm{T}$ lymphocytes and macrophages [54,55]. Mouse models of inflammation showed very similar infiltrative components as inflamed human prostates [56]. Th1 cells control the immune response to intracellular pathogens through interferon and IL-2. Type $1 \mathrm{~T}$ helper cells produce IL-4, IL-13, and IL-5 in the hypersensitivity response. Th17 cells appear as host defense against extracellular pathogens through IL-17 and IL21. Resident epithelial and stromal cells express several TLRs, including TLR-4, TLR-5, TLR-7, and TLR-9, and also produce IL-1, IL-6, and IL15 during inflammation [57]. Prostatic epithelial cells express Class II major histocompatibility complex molecules that participate in organspecific inflammation, resulting in the production of IL-6, IL-8, and CXCL10, and leukocyte recruitment [58]. Stromal cells express CD80, CD86, CD40, and CD134L and activate T lymphocytes directly. These activities contribute to a chronic state of inflammation.

\section{DIAGNOSIS}

Diagnosis of all type prostatitis is mentioned below [59].

\section{ABP}

1. Physical examination

2. Urine analysis and culture

3. Imaging

I. Transrectal prostatic ultrasound (TRUS) or computed tomography

II. Pelvic ultrasound or bladder scan.

\section{CHRONIC BACTERIAL PROSTATITIS}

1. Physical examination

2. Microbiological localization culture of a lower urinary tract I. 4-Glass test

II. 2-Glass Pre and Post Massage Test (PPMT).

3. Semen culture

4. TRUS

5. Urodynamic (examination for urine flow).

\section{CHRONIC PROSTATITIS/CPPS}

1. Symptoms scoring questionnaires (according to NIH-Chronic Prostatitis Symptoms Index)

2. Cystoscopy

3. Endoscopy (patients with hematuria) 
Table 1: Treatment of acute and chronic bacterial prostatitis [60]

\begin{tabular}{l}
\hline ABP \\
\hline Mild or moderate disease while anticipating culture \\
Trimethoprim $300 \mathrm{mg}$ taken orally 14 days [60], or \\
Cephalexin $500 \mathrm{mg}$ administered orally b.i.d for 14 days, or \\
Clavulanic acid and amoxicillin $125 \mathrm{mg}+500 \mathrm{mg}$ orally b.i.d for \\
14 days \\
Appears unable to resist or septic anticipated oral therapy \\
Admit to a hospital, offer parenteral treatment with ampicillin and \\
gentamycin or ceftriaxone as persevere pyelonephritis treatment \\
\hline Chronic bacterial prostate inflammation \\
\hline The first line of treatment \\
Norfloxacin $400 \mathrm{mg}$ is administered orally every $12 \mathrm{~h}$ for 4 weeks, or \\
Trimethoprim 300 mg orally daily for 4 weeks \\
If ureaplasma or chlamydia noted \\
Doxycycline $100 \mathrm{mg}$ given orally every $12 \mathrm{~h}$ for $2-4$ weeks \\
\hline
\end{tabular}

4. 4-glass test or PPMT

5. Physiological assessment.

The above categories of prostatitis diagnosed according to the patient symptoms, duration, and recurrence of the inflammation in the prostate gland. However, asymptomatic prostatitis is identified accidentally during the infertility evaluation.

\section{TREATMENT}

The treatment for the prostatitis is given broadly illustrating the medication, by indigenous system of medicines like allopathic, ayurvedic, acupuncture, phytotherapy, physical therapy and hormone therapy (Table 1).

\section{CHRONIC PROSTATITIS/CPPS}

\section{Alpha-blockers}

Five alpha reductase inhibitors such as finasteride and dutasteride, Alfuzosin, Tamsulosin, Doxazosin, Terazosin are broadly prescribed in the prostatitis patients [61]. These drugs are muscle relaxant at the bladder neck, facilitates the urine. These work by targeting the symptomatic relief of chronic prostatitis during the painful urination. Alpha-blocker has several side effects associated like dizziness, insomnia and vertigo. Nonselective alpha-blockers such as doxazosin and terazosin (Hytrin) must be used with care because they can excessively lower blood pressure. Mostly preferred alpha blockers are alfuzosin or tamsulosin produces improvement of urinary symptoms and QOL and less likely causes reduce in blood pressure.

\section{Anticholinergic}

These medications, which include tolterodine (Detrol) and oxybutynin (Ditropan), mainly reduce the urge to urinate by exhibiting the action of decreasing contraction of the bladder. Cause urinary retention may cause to the men suffering enlarged prostate [61].

\section{Nonsteroidal anti-inflammatory drug (NSAID)}

The NSAID drugs like Aspirin, ibuprofen, and naproxen sodium are prescribed, to reduce pain. NSAID is prescribed to reduce pain and also to reduce the inflammation pain. Fluoxetine (20 mg orally daily) generally prescribed for depression and to improved QOL [62]

\section{Neuromodulators}

Amitriptyline, Nortriptyline and pregabalin are new medication for the treatment of prostatitis, prescribed for the urinary frequency and urgency. Management of refractory CPP was performed by the stimulation of neuromodulation/nerve stimulation. Neuromodulation spot the S2-S4 nerve roots even though the pelvis is innervated by peripheral sympathetic (T12-L2) and somatic (S2-4), as well as parasympathetic (S2-4) nerve structures. Therefore, the exact painful location is covered by lead placement at the sacral level, but not a satisfactory improvement symptomatically is notice in patients [63]

\section{Muscle relaxant}

Cyclobenzaprine, Clonazepam extensively used muscle relaxant. Diazepam and baclofen can be used in Category IIIB prostatitis when sphincter dyssynergia or pelvic floor/perineal muscle spasm is confirmed. The evidence for this is rather old [64], and the role of these agents has not re-evaluated subsequently. They act as a calming agent to the central nervous system, help with anxiety, and relax the pelvic muscles, thereby reducing muscle spasms. Muscle relaxants are helpful in easing the pain and pressure that many CPPS patients experience.

\section{Phytotherapy}

Phytotherapies (specifically quercetin and the pollen extract, saw palmetto cernilton) $[65,66]$ are optional recommendations for the first line of chronic bacterial prostatitis and combination multimodal therapy.

\section{Acupuncture}

Acupuncture as an effective treatment to improve symptoms of $\mathrm{CP} / \mathrm{CPPS}$. Compared with sham acupuncture, real acupuncture leads to significant reductions in the pain, urinary symptoms, and QOL domains of the NIH chronic prostatitis symptom index [67].

\section{PHYSICAL THERAPY}

\section{Kegel exercises}

Tightening and relaxing the muscles that hold urine in the bladder and hold the bladder in its proper position also called pelvic muscle exercises.

\section{Myofascial release}

Myofascial release is a hand on technique that involves pressure into the connective tissue to eliminate pain and restore function and motion in affected area. Pressing and stretching of the particular region also practices like cooling and warming, of the muscles and soft tissues in the lower back, pelvic region, and upper legs leads to relief in pain. Also known as myofascial trigger point release (Table 2) [68].

\section{HORMONE THERAPY}

The principal activity in hormone therapy is blocking hormonal activity leads to the inhibition of growth of cancer cells, for example, luteinizing hormone producing hormones, which exhibits the mechanism of action that can cause gonadotropin secretion inhibition. Following an early stimulation of gonadotropin, testicular steroidogenesis suppression occurs due to long-term administration of leuprolide acetate. It results in inhibition of the growth of the specific hormone, proves and shows that luteinizing hormone-releasing hormone agonists promote tumors (such as prostatic tumors). Examples are buserelin, leuprolide, and goserelin [75]. Antiandrogens exert its action by inhibiting androgen uptake and by inhibiting nuclear binding of androgen to the androgen receptors on prostatic cells such as flutamide and nilutamide. Studies are still being accomplished to find the ideal therapy for localized prostate cancer

\section{Clinical management}

Clinical management of prostatitis is possible by avoiding ignorance of pain and its aided symptoms. Early detection of prostatitis is completely curable and monitoring the abnormalities after the recovery of the prostatitis is necessary. If the prostatitis is left untreated that leads to the chronic stage and later it causes enlargement associated hardening of the prostate gland that finally ends resulting in prostate cancer. Identification of the exact stage of prostate enlargement whether it is prostatitis or prostate cancer by a conventional test such as PSA and digital rectal exam for application in clinical practice [76]. There is a strong similarity among the clinical and molecular assays in identifying initially and robust cancer determination because molecular assays are less aggressive and reliable. The genetic markers have the ability to providing useful prognostic or 
Table 2: Treatment for different categories of prostatitis on crude drugs [69-74]

\begin{tabular}{|c|c|c|c|c|}
\hline S. No & Plant name & Family/part & $\begin{array}{l}\text { Primary secondary metabolites/ } \\
\text { mechanism of action }\end{array}$ & Activity exhibited \\
\hline 1 & Alisma plantago-aquatica Linnaeus [69] & Alismataceae & Terpenes and phenolic acid & $\begin{array}{l}\text { Anti-chronic prostatic } \\
\text { activity }\end{array}$ \\
\hline 2 & Phoenix dactylifera DPP [70] & Arecaceae & $\begin{array}{l}\text { The expressions of IL- } 6 \text {, IL- } 8 \text {, TNF- } \alpha \text {, } \\
\text { IGF-1, and clusterin increased, while the } \\
\text { expression of TGF- } \beta 1 \text { was decreased } \\
\text { that correlates with the presence of } \\
\text { inflammation }\end{array}$ & $\begin{array}{l}\text { Improve male } \\
\text { infertility, treats } \\
\text { atypical prostatic } \\
\text { hyperplasia, } \\
\text { anti-inflammatory, } \\
\text { anti-proliferative }\end{array}$ \\
\hline 3 & Cernitin pollen [71] & Graminaceae & $\begin{array}{l}\text { Decreased the increased contents of } \\
\text { cytokines }\end{array}$ & $\begin{array}{l}\text { Anti-inflammatory } \\
\text { action, an inhibitory } \\
\text { effect on the prostatic } \\
\text { inflammatory cytokine }\end{array}$ \\
\hline 4 & Tamala (Cinnamomumtamala) [72] & Lauraceae & $\begin{array}{l}\text { Tannins, COX- } 2 \text { inhibition is reported to } \\
\text { increase apoptotic activity in the prostatic } \\
\text { cell in human BPH tissue }\end{array}$ & $\begin{array}{l}\text { Anti-inflammatory, } \\
\text { anti-microbial, } \\
\text { antidiarrheal }\end{array}$ \\
\hline 6 & Cucurbitapeponis $[73,74]$ & Cucurbitaceae & $\begin{array}{l}\text { Sterols, carotenoids, minerals (Se, Mg) } \\
\text { and produces competitive binding to } \\
\text { androgen receptors, decreased binding } \\
\text { capacity of the androgen receptor to } \\
\text { testosterone }\end{array}$ & $\begin{array}{l}\text { Diuretic property, } \\
\text { Anthelmintic } \\
\text { properties }\end{array}$ \\
\hline 7 & Pygeumafricanum $[73,74]$ & Rosaceae & $\begin{array}{l}\text { Phytosterols (beta-sitosterol), triterpenes, } \\
\text { long-chain fatty acids Its MOA inhibits } \\
\text { either androgens or } 5 \alpha \text {-reductase, it may } \\
\text { have direct protective effects by restoring } \\
\text { structural and functional characteristics } \\
\text { in the aging prostate }\end{array}$ & Treatment of BPH \\
\hline 8 & Urticadioica radix $[73,74]$ & Urticaceae & $\begin{array}{l}\text { Its active phytochemical constituents } \\
\text { are Lectins, phenol, sterols, lignans MOA } \\
\text { is binding to SHBG, inhibition of cell } \\
\text { proliferation, Na+-K+-ATPase inhibition }\end{array}$ & $\begin{array}{l}\text { Anti-inflammatory } \\
\text { effects decrease } \\
\text { growth factor }\end{array}$ \\
\hline 9 & Allium sativum (garlic) [75] & Amaryllidaceae & $\begin{array}{l}\text { The statistically significant decrease } \\
\text { in bacterial growth and improvement } \\
\text { in prostatic inflammation as well as a } \\
\text { synergistic effect with ciprofloxacin }\end{array}$ & $\begin{array}{l}\text { Useful in treating CBP } \\
\text { with a higher success } \\
\text { rate }\end{array}$ \\
\hline 10 & Secale cereale (Rye pollen) [74] & Pooideae & $\begin{array}{l}\text { Alpha amino acids, phytosterols, } \\
\text { carbohydrate }\end{array}$ & $\begin{array}{l}\text { Anti-inflammatory, } \downarrow \\
\text { urethral resistance }\end{array}$ \\
\hline 11 & $\begin{array}{l}\text { Hypoxis rooperi (South African star } \\
\text { grass) [74] }\end{array}$ & Hypoxidaceae & $\begin{array}{l}\text { Beta-sitosterol, other phytosterols, } \\
\text { its action is a decrease in ATPase, a } \\
\text { reduction in cell growth }\end{array}$ & $\begin{array}{l}\text { Anti-inflammatory } \\
\text { decreases the prostate } \\
\text { inflammation }\end{array}$ \\
\hline
\end{tabular}

DPP: Date palm pollen, SHBG: Sex hormone binding globulin, MOA: Memorandum of agreement, CBP: Customs and border protection

predictive information into clinically useful diagnostic tests to improve clinical decision-making and enhance therapeutic success.

\section{CONCLUSION}

The prostatitis is one of the most common diseases that affect men. Treatment of this diseases has to perform according to the patient's sign and symptoms and also the duration of the illness has to consider deeply to identify the category of the prostate inflammation and to provide appropriate treatment. Various diagnostic procedures have to undergo for critical analysis of the type of prostatitis. Many types of research are emerging for the treatment of chronic prostatitis in multiple fields such as Ayurveda, acupuncture, and physical therapy. Clinical trials are under process for hormonal therapy for the curative purpose. The researchers are targeting on the anti-inflammatory activity on prostatitis from the active phytochemical and isolated compound in natural or crude drugs.

\section{ACKNOWLEDGMENT}

I am highly indebted to SRM Institute of Science and Technology management and staffs for the valuable guidance and constant supervision for supporting to complete this review.

\section{AUTHORS' CONTRIBUTIONS}

All the authors in this review literature have given an equal contribution and for collecting the information and compiling the data.

\section{CONFLICTS OF INTEREST}

The author declares that we did not have the conflicts of interest for collecting the information of compiling this article and also for the paper publication. 


\section{REFERENCES}

1. Available from: https://www.livescience.com/32751-what-does-theprostate-gland-do.html.

2. Krieger JN, Nyberg L Jr., Nickel JC. NIH consensus definition and classification of prostatitis. JAMA 1999;282:236-7.

3. Schaeffer AJ. Clinical practice. Chronic prostatitis and the chronic pelvic pain syndrome. N Engl J Med 2006;355:1690-8

4. Skerk V, Krhen I, Schonwald S, Cajic V, Markovinovic L, Roglic S, et al. The role of unusual pathogens in prostatitis syndrome. Int $\mathrm{J}$ Antimicrob Agents 2004;24 Suppl 1:S53-6.

5. Morgia G, Mucciardi G, Galì A, Madonia M, Marchese F, Di Benedetto A, et al. Treatment of chronic prostatitis/chronic pelvic pain syndrome category IIIA with Serenoa repens plus selenium and lycopene (Profluss) versus $S$. repens alone: An Italian randomized multicenter-controlled study. Urol Int 2010;84:400-6.

6. Krieger JN, Riley DE. Prostatitis: What is the role of infection. Int J Antimicrob Agents 2002;19:475-9.

7. Murphy AB, Macejko A, Taylor A, Nadler RB. Chronic prostatitis: Management strategies. Drugs 2009;69:71-84.

8. Leskinen MJ, Rantakokko-Jalava K, Manninen R, Leppilahti M, Marttila T, Kylmälä T, et al. Negative bacterial polymerase chain reaction (PCR) findings in prostate tissue from patients with symptoms of chronic pelvic pain syndrome (CPPS) and localized prostate cancer. Prostate 2003;55:105-10.

9. Lee JC, Muller CH, Rothman I, Agnew KJ, Eschenbach D, Ciol MA, et al. Prostate biopsy culture findings of men with chronic pelvic pain syndrome do not differ from those of healthy controls. J Urol 2003;169:584-7.

10. Anderson RU, Orenberg EK, Morey A, Chavez N, Chan CA. Stress induced hypothalamus-pituitary-adrenal axis responses and disturbances in psychological profiles in men with chronic prostatitis/ chronic pelvic pain syndrome. J Urol 2009;182:2319-24.

11. Nickel JC, Roehrborn CG, O'leary MP, Bostwick DG, Somerville MC, Rittmaster RS, et al. Examination of the relationship between symptoms of prostatitis and histological inflammation: Baseline data from the REDUCE chemoprevention trial. J Urol 2007;178:896-900.

12. Rodríguez MA, Afari N, Buchwald DS; National Institute of Diabetes and Digestive and Kidney Diseases Working Group on Urological Chronic Pelvic Pain. Evidence for overlap between urological and nonurological unexplained clinical conditions. J Urol 2009;182:2123-31.

13. Trinchieri A, Magri V, Cariani L, Bonamore R, Restelli A, Garlaschi MC, et al. Prevalence of sexual dysfunction in men with chronic prostatitis/ chronic pelvic pain syndrome. Arch Ital Urol Androl 2007;79:67-70

14. Krieger JN, Ross SO, Penson DF, Riley DE. Symptoms and inflammation in chronic prostatitis/chronic pelvic pain syndrome. Urology 2002;60:959-63.

15. Nickel JC, Weidner W. Chronic prostatitis: Current concepts and antimicrobial therapy. Infect Urol 2000;13:s22-8.

16. Gandaglia G, Zaffuto E, Fossati N, Cucchiara V, Mirone V, Montorsi F, et al. The role of prostatic inflammation in the development and progression of benign and malignant diseases. Curr Opin Urol 2017;27:99-106.

17. Chen CS, Chang PJ, Lin WY, Huang YC, Ho DR. Evidences of the inflammasome pathway in chronic prostatitis and chronic pelvic pain syndrome in an animal model. Prostate 2013;73:391-7.

18. Kummer JA, Broekhuizen R, Everett H, Agostini L, Kuijk L, Martinon $\mathrm{F}$, et al. Inflammasome components NALP 1 and 3 show distinct but separate expression profiles in human tissues suggesting a site-specific role in the inflammatory response. J Histochem Cytochem 2007:55:443-52.

19. Ponomareva L, Liu H, Duan X, Dickerson E, Shen H, Panchanathan R, et al. AIM2, an IFN-inducible cytosolic DNA sensor, in the development of benign prostate hyperplasia and prostate cancer. Mol Cancer Res 2013;11:1193-202.

20. Roehrborn CG. BPH progression: Concept and key learning from MTOPS, ALTESS, COMBAT, and ALF-ONE. BJU Int 2008;101 Suppl 3:17-21.

21. Ficarra V, Rossanese M, Zazzara M, Giannarini G, Abbinante M, Bartoletti $\mathrm{R}$, et al. The role of inflammation in lower urinary tract symptoms (LUTS) due to benign prostatic hyperplasia (BPH) and its potential impact on medical therapy. Curr Urol Rep 2014;15:463.

22. Gandaglia G, Briganti A, Gontero P, Mondaini N, Novara G, Salonia A, et al. The role of chronic prostatic inflammation in the pathogenesis and progression of benign prostatic hyperplasia (BPH). BJU Int 2013;112:432-41.

23. Elkahwaji JE. The role of inflammatory mediators in the development of prostatic hyperplasia and prostate cancer. Res Rep Urol 2012;5:1-10.
24. Nguyen DP, Li J, Yadav SS, Tewari AK. Recent insights into NF-кB signalling pathways and the link between inflammation and prostate cancer. BJU Int 2014;114:168-76.

25. Bauernfeind FG, Horvath G, Stutz A, Alnemri ES, MacDonald K, Speert D, et al. Cutting edge: NF-kappaB activating pattern recognition and cytokine receptors license NLRP3 inflammasome activation by regulating NLRP3 expression. J Immunol 2009;183:787-91.

26. Moreira DM, Nickel JC, Gerber L, Muller RL, Andriole GL, CastroSantamaria $\mathrm{R}$, et al. Baseline prostate inflammation is associated with a reduced risk of prostate cancer in men undergoing repeat prostate biopsy: Results from the REDUCE study. Cancer 2014;120:190-6.

27. Yli-Hemminki TH, Laurila M, Auvinen A, Määttänen L, Huhtala $H$, Tammela TL, et al. Histological inflammation and risk of subsequent prostate cancer among men with initially elevated serum prostatespecific antigen (PSA) concentration in the Finnish prostate cancer screening trial. BJU Int 2013;112:735-41

28. Powell IJ, Dyson G, Land S, Ruterbusch J, Bock CH, Lenk S, et al. Genes associated with prostate cancer are differentially expressed in African American and European American men. Cancer Epidemiol Biomarkers Prev 2013;22:891-7.

29. Wallace TA, Prueitt RL, Yi M, Howe TM, Gillespie JW, Y fantis HG, et al. Tumor immunobiological differences in prostate cancer between African-American and European-American men. Cancer Res 2008;68:927-36.

30. Videčnik Zorman J, Matičič M, Jeverica S, Smrkolj T. Diagnosis and treatment of bacterial prostatitis. Acta Dermatovenerol Alp Pannonica Adriat 2015;24:25-9.

31. Kirby RS, Lowe D, Bultitude MI, Shuttleworth KE. Intra-prostatic urinary reflux: An aetiological factor in abacterial prostatitis. Br J Urol 1982;54:729-31.

32. Nyberg LM, Krieger JN, Nickel JC. Textbook of Prostatitis. Oxford, United Kingdom: National Institutes of Health Classification of Chronic Prostatitis; 1999. p. 27-9.

33. Weiss J, Wein A, Jacobs J, Hanno P. Use of nitrofurantoin macrocrystals after transurethral prostatectomy. J Urol 1983;130:479-80

34. De Nunzio C, Aronson W, Freedland SJ, Giovannucci E, Parsons JK. The correlation between metabolic syndrome and prostatic diseases. Eur Urol 2012;61:560-70.

35. Freeman MR, Solomon KR. Cholesterol and benign prostate disease. Differentiation 2011;82:244-52.

36. Vignozzi L, Gacci M, Maggi M. Lower urinary tract symptoms, benign prostatic hyperplasia and metabolic syndrome. Nat Rev Urol 2016;13:108-19.

37. Moreira DM, Nickel JC, Gerber L, Muller RL, Andriole GL, CastroSantamaria R, et al. Smoking is associated with acute and chronic prostatic inflammation: Results from the REDUCE study. Cancer Prev Res (Phila) 2015;8:312-7.

38. Shankar E, Bhaskaran N, MacLennan GT, Liu G, Daneshgari F, Gupta $\mathrm{S}$, et al. Inflammatory signaling involved in high-fat diet induced prostate diseases. J Urol Res 2015;2:1018.

39. Ghaemi-Oskouie F, Shi Y. The role of uric acid as an endogenous danger signal in immunity and inflammation. Curr Rheumatol Rep 2011;13:160-6.

40. Lamkanfi M, Dixit VM. Mechanisms and functions of inflammasomes. Cell 2014;157:1013-22.

41. Sutterwala FS, Haasken S, Cassel SL. Mechanism of NLRP3 inflammasome activation. Ann N Y Acad Sci 2014;1319:82-95.

42. Wen H, Miao EA, Ting JP. Mechanisms of NOD-like receptorassociated inflammasome activation. Immunity 2013;39:432-41.

43. He WT, Wan H, Hu L, Chen P, Wang X, Huang Z, et al. Gasdermin D is an executor of pyroptosis and required for interleukin- $1 \beta$ secretion. Cell Res 2015;25:1285-98.

44. Kayagaki N, Stowe IB, Lee BL, O'Rourke K, Anderson K, Warming S, et al. Caspase-11 cleaves gasdermin D for non-canonical inflammasome signalling. Nature 2015;526:666-71.

45. Shi J, Zhao Y, Wang Y, Gao W, Ding J, Li P, et al. Inflammatory caspases are innate immune receptors for intracellular LPS. Nature 2014;514:187-92.

46. Shi Y, Evans JE, Rock KL. Molecular identification of a danger signal that alerts the immune system to dying cells. Nature 2003;425:516.

47. Kayagaki N, Wong MT, Stowe IB, Ramani SR, Gonzalez LC, Akashi-Takamura S, et al. Noncanonical inflammasome activation by intracellular LPS independent of TLR4. Science 2013;25:1240-8.

48. Guo H, Callaway JB, Ting JP. Inflammasomes: Mechanism of action, role in disease, and therapeutics. Nat Med 2015;21:677-87.

49. Jiménez Fernández D, Lamkanfi M. Inflammatory caspases: Key regulators of inflammation and cell death. Biol Chem 2015;396:193-203. 
50. Roberts JS, Yilma Z. Dangerous liaisons: Caspase-11 and reactive oxygen species crosstalk in pathogene limination. Int $\mathrm{J}$ Mol Sci 2015; $16: 23337-54$

51. Lotti F, Maggi M. Interleukin 8 and the male genital tract. J Reprod Immunol 2013;100:54-65

52. Boehm BJ, Colopy SA, Jerde TJ, Loftus CJ, Bushman W. Acute bacterial inflammation of the mouse prostate. Prostate 2012;72:307-17.

53. Steiner GE, Stix U, Handisurya A, Willheim M, Haitel A, Reithmayr F, et al. Cytokine expression pattern in benign prostatic hyperplasia infiltrating $\mathrm{T}$ cells and impact of lymphocytic infiltration on cytokine mRNA profile in prostatic tissue. Lab Invest 2003;83:1131-46.

54. Theyer G, Kramer G, Assmann I, Sherwood E, Preinfalk W, Marberger $\mathrm{M}$, et al. Phenotypic characterization of infiltrating leukocytes in benign prostatic hyperplasia. Lab Invest 1992;66:96-107.

55. Haverkamp JM, Charbonneau B, Crist SA, Meyerholz DK, Cohen MB, Snyder PW, et al. An inducible model of abacterial prostatitis induces antigen specific inflammatory and proliferative changes in the murine prostate. Prostate 2011;71:1139-50.

56. Kramer G, Mitteregger D, Marberger M. Is benign prostatic hyperplasia (BPH) an immune inflammatory disease? Eur Urol 2007;51:1202-16.

57. Penna G, Fibbi B, Amuchastegui S, Cossetti C, Aquilano F, Laverny G, et al. Human benign prostatic hyperplasia stromal cells as inducers and targets of chronic immuno-mediated inflammation. J Immunol 2009; 182:4056-64

58. Nickel JC. Prostatitis. Can Urol Assoc J 2011;5:306-15.

59. Horcajada JP, Vilana R, Moreno-martínez A, Alvarez-vijande R, Bru $\mathrm{C}$, Bargalló $\mathrm{X}$, et al. Transrectal prostatic ultrasonography in acute bacterial prostatitis: Findings and clinical implications. Scand J Infect Dis 2003;35:114-20.

60. Dickson G. Prostatitis: Diagnosis and treatment. Aust Fam Physician 2013;42:216

61. Xia D, Wang P, Chen J, Wang S, Jiang H. Fluoxetine ameliorates symptoms of refractory chronic prostatitis/chronic pelvic pain syndrome. Chin Med J (Engl) 2011;124:2158-61.

62. Tirlapur SA, Vlismas A, Ball E, Khan KS. Nerve stimulation for chronic pelvic pain and bladder pain syndrome: A systematic review. Acta Obstet Gynecol Scand 2013;92:881-7.

63. Osborn DE, George NJ, Rao PN, Barnard RJ, Reading C, Marklow C, et al. Prostatodynia - physiological characteristics and rational management with muscle relaxants. Br J Urol 1981;53:621-3.

64. Buck AC, Rees RW, Ebeling L. Treatment of chronic prostatitis and prostatodynia with pollen extract. Br J Urol 1989;64:496-9.

65. Shoskes DA, Zeitlin SI, Shahed A, Rajfer J. Quercetin in men with category III chronic prostatitis: A preliminary prospective, doubleblind, placebo-controlled trial. Urology 1999;54:960-3.

66. Capodice JL, Jin Z, Bemis DL, Samadi D, Stone BA, Kapan S, et al. A pilot study on acupuncture for lower urinary tract symptoms related to chronic prostatitis/chronic pelvic pain. Chin Med 2007;2:1

67. Nickel JC. Prostatitis and related conditions, orchitis, and epididymitis. In: Wein AJ, Kavoussi LR, Novick AC, Partin AW, Peters CA, editors. Campbell-Walsh Urology. $10^{\text {th }}$ ed. Philadelphia, PA: Saunders; 2012. p. 327-56.

68. Huang YS, Yu QQ, Chen Y, Cheng MJ, Xie LP. Phenolic constituents from Alisma plantago-aquatica Linnaeus and their anti-chronic prostatitis activity. Chem Cent J 2017;11:120.

69. Elberry AA, Mufti ST, Al-Maghrabi JA, Abdel-Sattar EA, Ashour OM, Ghareib SA, et al. Anti-inflammatory and antiproliferative activities of date palm pollen (Phoenix dactylifera) on experimentally-induced atypical prostatic hyperplasia in rats. J Inflamm (Lond) 2011;8:40

70. Asakawa K, Nandachi N, Satoh S, Honma M, Namikata S, Ishii M, et al. Effects of cernitin pollen-extract (Cernilton) on inflammatory cytokines in sex-hormone-induced nonbacterial prostatitis rats. Hinyokika Kiyo 2001;47:459-65.

71. Dumbre RK, Kamble MB, Patil VR. Inhibitory effects by Ayurvedic plants on prostate enlargement induced in rats. Pharmacognosy Res 2014;6:127-32

72. Dvorkin L, Song KY. Herbs for benign prostatic hyperplasia. Ann Pharmacother 2002;36:1443-52.

73. Curtis Nickel J, Shoskes D, Roehrborn CG, Moyad M. Nutraceuticals in prostate disease: The urologist's role. Rev Urol 2008;10:192-206.

74. Sohn DW, Han CH, Jung YS, Kim SI, Kim SW, Cho YH, et al. Antiinflammatory and antimicrobial effects of garlic and synergistic effect between garlic and ciprofloxacin in a chronic bacterial prostatitis rat model. Int J Antimicrob Agents 2009;34:215-9.

75. Rani P, Singh K, Devi S, Arjuna A. Detection of prostate cancer: A Review. Asian J Pharm Clin Res 2018;11:974-2441.

76. Mansouri F. The role of the clinical and molecular assays in prostate cancer detection. Asian J Pharm Clin Res 2017;10:11-5. 